\title{
Pengaruh Work Family Conflict Terhadap Pengembangan Karier
}

\author{
Diny Atrizka, Agung Maliki Herman, Jevika Luincky, Mona Elisa Putri Simanjuntak, dan Paskal \\ Jevon Dachi \\ Universitas Prima Indonesia, Indonesia \\ Email: diny.dinyrizk@gmail.com, agungmaliki4720@gmail.com, luinckyjevika@gmail.com, Jevondachi03@gmail.com,
} monaputry130@gmail.com

\begin{abstract}
This study aims to look at the effect of work family conflict on career development. The subjects used in this study were 196 police officers in the North Sumatra Regional Police Directorate General of Criminal Investigation. The hypothesis proposed in this study states that the influence of work family conflict on career development, where work family conflict tends to undermine the career development of a police officer. Analysis of the data used in this study is Correlational Analysis through the help of SPSS 25 for windows. The results of correlation analysis correlation values $(r)$ of -0.416 with $p=0.000(P<0.05)$. This research shows that the contribution of Adjust $R$ Square given to work family conflict on career development is 16.9\%, the remaining $83.1 \%$ is influenced by other factors. With this result it shows that there is a negative relationship between work family conflict and career development, where work family conflict significantly influences career development.
\end{abstract}

Keywords: carrier development, work family conflict, police officer

\begin{abstract}
Abstrak
Penelitian ini bertujuan untuk melihat pengaruh work family conflict terhadap pengembangan karier. Subjek yang digunakan dalam penelitian ini adalah anggota kepolisian yang berada di bagian Ditreskrimum berjumlah 196 orang di Polda Sumatera Utara. Hipotesis yang diajukan dalam penelitian ini menyatakan bahwa adanya pengaruh work family conflict terhadap pengembangan karier, di mana work family conflict cenderung melemahkan pengembangan karier seorang polisi. Analisis data yang digunakan dalam penelitian ini adalah Analisis Korelasional melalui bantuan SPSS 25 for windows. Hasil analisis korelasi diperoleh nilai korelasi (r) sebesar -0.416 dengan $\mathrm{p}=0.000$ ( $\mathrm{p}<0.05$ ). Pada penelitian ini menunjukkan bahwa sumbangan Adjust $R$ Square yang diberikan work family conflict terhadap pengembangan karier sebesar $16.9 \%$, selebihnya $83,1 \%$ dipengaruhi oleh faktor lain. Dengan hasil ini menunjukkan bahwa adanya hubungan negatif antara work family conflict dengan pengembangan karier, di mana work family conflict secara signifikan mempengaruhi pengembangan karier.
\end{abstract}

Kata kunci: pengembangan karier, konflik pekerjaan keluarga, anggota polisi

\section{Pendahuluan}

Organisasi dapat diartikan sebagai kumpulan orang-orang yang bersepakat untuk berinteraksi dan bekerja sama secara terstruktur guna mencapai tujuan bersama yang telah ditetapkan, maka peranan orang-orang yang terlibat di dalam organisasi sangatlah penting. Organisasi adalah sekelompok orang yang bertindak bersama untuk menghasilkan manfaat yang memuaskan bagi para penerima manfaatnya [1]. Pada umumnya organisasi dijalankan secara bersama-sama agar semua bagian di dalam organisasi bertindak, bekerja berdasarkan tugas dan fungsi masing- masing, saling berkoordinasi dengan bagian lain tanpa mengintervensi, dan tumpang tindih kewajiban dengan orang lain. Hal tersebut bisa mencapai efisiensi baik secara waktu (bekerja tepat waktu) maupun secara biaya (tidak ada pemborosan dana) dan seterusnya efektif kerja bisa dicapai, sehingga pada akhirnya hasil yang dicapai dapat maksimal. Banyak contoh dari organisasi dalam kehidupan masyarakat di antaranya organisasi di sekolah, masyarakat, dan pemerintahan. Salah satu organisasi di pemerintahan yang bergerak dalam bidang keamanan adalah Kepolisian.

Hermer, dkk., [2] mendefinisikan kepolisian sebagai kegiatan apa pun yang dirancang secara tegas dan dimaksudkan untuk menetapkan dan memelihara (atau menegakkan) tatanan yang ditentukan dalam

Diterima Redaksi : 04-20-2021 | Selesai Revisi : 05-25-2021 | Diterbitkan Online : 06-05-2021 
suatu komunitas. Kepolisian memiliki dalam hal bidang pemeliharaan keamanan dan ketertiban masyarakat; penegakan hukum; perlindungan; pengayoman; serta pelayanan kepada masyarakat dengan memerhatikan semangat penegak hak asasi manusia (HAM), hukum, dan keadilan.

Berkaitan dengan tugasnya sebagai anggota kepolisian yang bertugas dalam penegakan hukum, perlindungan, pengayoman, dan pelayanan kepada masyarakat, seorang anggota polisi juga sama halnya seperti masyarakat pada umumnya, yakni pernah melakukan kesalahan dalam hidupnya, sehingga pada akhirnya mempengaruhi kehidupannya dalam berkeluarga dan pekerjaannya. Sebagai bagian dari hal tersebut ditemukan beberapa polisi mengalami permasalahan yang di mana seorang anggota polisi menembak istrinya sendiri, hal tersebut berawal dari sebuah permasalahan rumah tangga (liputan6.com). Selain itu juga ditemukan seorang anggota polisi menembak rekannya sendiri, yang pada akhirnya polisi tersebut dijatuhi hukuman mati (metro.tempo.co). Permasalahan tersebut berdampak pada karier anggota polisi itu sendiri. Adanya permasalahan dapat menyebabkan terhambatnya pengembangan karier seorang anggota polisi.

Dapat dikatakan seorang anggota polisi juga memiliki sebuah permasalahan yang dampaknya berujung pada kariernya sebagai anggota kepolisian. Berdasarkan hasil observasi dan wawancara yang dilakukan di Polda Sumatera Utara, diketahui sebagian dari anggota kepolisian baik pada polisi lakilaki dan polisi wanita menyatakan juga sulit menyeimbangkan antara tugas-tugas di pekerjaan dan tugas-tugas di dalam keluarga. Khususnya ketidakseimbangan ini dialami oleh polisi wanita, yaitu ketika kehadirannya dibutuhkan oleh seorang anak, seperti pada saat anak sedang sakit, saat anak ada acara di sekolah, dan saat acara keagamaan. Kesulitan dalam menyeimbangkan tugas-tugasnya ini tidak hanya terjadi pada polisi wanita, tetapi juga dialami oleh polisi laki-laki. Hasil wawancara menyatakan ada beberapa polisi laki-laki yang memiliki permasalahan dalam keluarga yang berujung pada demosi jabatan. Ketidakseimbangan tersebut menjadikan beberapa polisi mengalami permasalahan dalam pengembangan kariernya.

Herr dan Cramer [3] mengatakan pengembangan karier mengacu pada proses psikologis dan perilaku seumur hidup serta pengaruh kontekstual yang membentuk karier seseorang selama masa hidup yang melibatkan penciptaan pola karier seseorang, gaya pengambilan keputusan, integrasi peran kehidupan, ekspresi nilai-nlai dan konsep diri peran kehidupan. Definisi lainnya menurut Martoyo [4] pengembangan karier adalah kondisi yang menunjukkan adanya sebuah peningkatan status seseorang pada suatu organisasi dalam jalur karier yang sudah ditetapkan.

Kadarko, dkk. [5] mengatakan bahwa pengembangan karier merupakan kegiatan formal dan berkelanjutan sebagai upaya untuk mengembangkan dan memperkaya sumber daya manusia dengan menyelaraskan sebutuhan karyawan sesuai karier, seperti faktor individu, kepribadian, hal yang ditawarkan kebutuhan diri dan kebutuhan sosial. Adapun dimensi dari pengembangan karier menurut Handoko [6] adalah eksposure, permintaan berhenti, kesetiaan organisasional, mentor dan sponsor, dan kesempatan-kesempatan untuk tumbuh.

Konflik menurut Robbins [7] adalah kondisi yang mempersepsikan di antara dua pihak atau lebih yang merasakan adanya ketidaksesuaian antara tujuan dan peluang untuk mencampur usaha pencapaian tujuan ke pihak lain. Salah satu bentuk konflik dari konflik antar peran ini adalah work family conflict. Work family conflict atau konflik peran ganda menurut Greenhaus dan Beuthel [7] adalah konflik peran ganda dalam diri seseorang yang muncul karena adanya tekanan peran dari pekerjaan ke dalam peran keluarga. Definisi lainnya menurut Sekaran [8] konflik peran ganda adalah permasalahan yang di alami oleh ibu rumah tangga, baik sebagai istri atau karyawan dalam memperoleh kehidupan sosial yang lebih baik. Hai dan Tziner [5] mengatakan work family conflict adalah istilah untuk menggambarkan suatu gangguan yang disebabkan oleh ketidakseimbangan pekerjaan kantoran professional dengan kepentingan pribadi keluarga. Suatu ketidakcocokan antara peran internal untuk memenuhi kebutuhan keluarga dengan peran eksternal sebagai pekerja profesional dalam pencapaian kinerjanya memicu konflik. 
Greenhaus dan Beutell [9] menjabarkan indikator dari work family conflict, yaitu (1) time-based conflict merupakan konflik yang terjadi karena waktu yang dibutuhkan untuk menjalankan salah satu tuntutan (keluarga atau pekerjaan) dapat mengurangi waktu untuk menjalankan tuntutan yang lainnya (pekerjaan atau keluarga). (2) strain-based conflict yaitu konflik yang terjadi pada saat tekanan dari salah satu peran memengaruhi kinerja peran yang lainnya. (3) behavior-based conflict yaitu konflik yang terjadi berhubungan dengan ketidaksesuaian antara pola perilaku yang diinginkan oleh kedua bagian (pekerjaan atau keluarga).

Penelitian yang dilakukan Wang [10] pada guru perempuan di University Lin Yi dan Shandong Medical College di Cina, menunjukkan terdapat pengaruh work family conflict terhadap career development. Pengaruh tersebut menunjukkan work family conflict melemahkan career development. Selain itu penelitian lain dari Hasnidar [5] menyatakan adanya hubungan negatif antara work family conflict terhadap pengembangan karier seseorang.

Selanjutnya penelitian yang dilakukan Estikomah [11] pada anggota polisi wanita di Yogyakarta, menunjukkan pengembangan karier juga dapat sebagai faktor dalam meningkatkan kesejahteraan psikologis. Lebih lanjut, dalam penelitian yang dilakukan oleh Nurak [12] terhadap pekerja perempuan di Indonesia bahwa adanya perbedaan antara perilaku yang diinginkan oleh kedua bagian (keluarga atau pekerjaan), maka pada seorang wanita tidak mampu mengembangkan kariernya dengan baik.

Dapat disimpulkan bahwa anggota polisi mempunyai peran ganda sebagai anggota kepolisian yang menjalankan tugas negara seperti pengayom, pengaman, pelindung, dan pelayan masyarakat. Tentunya sebagai seorang anggota kepolisian memiliki jabatan tertentu dalam profesinya, sehingga hal tersebut memungkin seorang anggota polisi mengalami konflik dalam pekerjaannya maupun dalam keluarganya. Berdasarkan uraian di atas, muncul rumusan masalah, yaitu: Apakah ada pengaruh work family conflict terhadap pengembangan karier anggota polisi? dan Bagaimana pengaruh work family conflict terhadap pengembangan karier anggota polisi?. Penelitian ini dilakukan dengan tujuan mengetahui pengaruh work family conflict terhadap pengembangan karier seorang anggota polisi. Adapun manfaat penelitian ini adalah sebagai bahan masukan untuk instasnsi khususnya pihak kepolisian dalam mengelola sumber daya manusia dengan baik sehingga meminimalisir tingkat perputaran pegawai atau karyawan di sebuah instansi dan sebagai tambahan rujukan dalam bidang psikologi industri dan organisasi terkait konflik yang terjadi pada pegawai atau karyawan.

\section{Metode Penelitian}

Penelitian ini merupakan penelitian kuantitatif, di mana populasi yang diteliti adalah seluruh anggota kepolisian bagian Ditreskrimum Polda Sumatera Utara. Sugiyono [13] mengatakan populasi adalah wilayah generalisasi yang terdiri atas objek atau subjek yang memiliki kualitas dan karakteristik tertentu yang ditetapkan oleh peneliti untuk dipelajari dan kemudian ditarik kesimpulannya.

Sampel yang digunakan dalam penelitian ini adalah seluruh personil anggota kepolisian bagian Ditreskrimum Polda Sumatera Utara, dengan jumlah sampel penelitian adalah sebanyak 196 orang. Sastroasmoro [13] mengatakan sampel adalah bagian dari populasi yang dipilih dengan cara tertentu. Teknik pengambilan sampel menggunakan teknik total sampling, yang dalam hal ini menurut Sugiyono [13] teknik total sampling merupakan teknik penentuan yang di mana semua anggota populasi digunakan sebagai sampel.

Variabel bebas yang digunakan adalah work family conflict, variabel bebas adalah variabel yang sifatnya mempengaruhi variabel yang lain dan pengaruhnya ingin diketahui [14]. Variabel terikat yang digunakan adalah pengembangan karier, variabel terikat merupakan variabel yang diukur untuk mengetahui besar atau tidaknya suatu pengaruh dari variabel lain [14].

Metode pengumpulan data pada penelitian ini menggunakan skala yang mengukur pengembangan karier, terdiri dari eksposur, permintaan berhenti, kesetiaan organisasional, mentor dan sponsor, dan kesempatan-kesempatan untuk tumbuh. Selanjutnya skala yang mengukur work family conflict, terdiri dari time-based conflict, strain-based conflict, dan behavior-based conflict. 
Pernyataan-pernyataan yang telah disusun dalam bentuk skala kemudian diukur menggunakan Skala Likert. Skala yang digunakan pada penelitian ini terdiri dari dua skala, yaitu skala pengembangan karier dan skala work family conflict. Skala pengembangan karier terdiri dari 40 butir pernyataan, dengan 20 butir pernyataan favorable dan 20 pernyataan unfavorable. Kemudian untuk skala work family conflict terdiri dari 30 butir pernyataan, dengan 15 butir pernyataan favorable dan 15 pernyataan unfavorable.

Validitas merupakan kemampuan suatu alat ukur untuk mengukur sasaran ukurnya [13]. Uji validitas pada penelitian ini adalah validitas isi, yang menurut Azwar [13] adalah sejauh mana aitem-aitem mencakup keseluruhan kawasan pada objek yang hendak diukur. Azwar [15] mengatakan suatu aitem dikatakan memadai untuk digunakan hendaknya memiliki koefisien dengan nilai 0,3 , namun apabila nilai koefisien yang dimiliki suatu aitem kurang dari 0,3 maka dianggap sebagai tidak memadai.

Reliabilitas mengacu kepada keterpercayaan atau konsistensi alat ukur [15]. Nilai reliabilitas dalam penelitian ini dapat dilihat dari nilai koefisien Alpha Cronbach. Kemudian Analisis data dalam penelitian ini yaitu menggunakan teknik analisis Korelasi Pearson Product Moment.

\section{Hasil dan Pembahasan}

Pelaksanaan penelitian menggunakan skala perkembangan karier, dan skala work family conflict. Adapun subjek penelitian skala ini adalah seluruh anggota polisi di bagian Ditreskrimum yang berjumlah 196 orang. Bentuk skala yang dipergunakan berupa skala likert yang disusun dalam bentuk angket yang nantinya akan disebarkan ke beberapa anggota kepolisian. Setelah dikumpulkan, maka dilakukan skoring, uji validitas serta uji reliabilitas.

Pada skala perkembangan karier, hasil pengujian terhadap validitas dan reliabilitas menunjukkan bahwa 31 dari 40 aitem dinyatakan sahih/layak. Pada tabel corrected item total correlation berdasarkan $\mathrm{r}$ minimal 0,30 dengan nilai $\mathrm{r}$ bergerak dari $0.362-0.697$. Dengan demikian, aitem yang gugur adalah sebanyak 9 aitem dengan nilai Alpha Cronbach sebesar 0.936. Hal ini berarti bahwa skala ini layak digunakan sebagai alat pengumpulan data dalam penelitian ini.

Pada skala work family conflict, hasil pengujian terhadap validitas dan reliabilitas menunjukkan bahwa 27 dari 30 aitem dinyatakan sahih/layak. Pada tabel corrected item total correlation berdasarkan $\mathrm{r}$ minimal 0,30 dengan nilai $r$ bergerak dari $0.367-0.835$. Dengan demikian, aitem yang gugur adalah sebanyak 3 aitem, dengan nilai Alpha Cronbach sebesar 0.952. Hal ini berarti bahwa skala ini layak digunakan sebagai alat pengumpulan data dalam penelitian ini.

Metode analisis data yang digunakan dalam penelitian ini adalah analisis korelasional. Metode ini digunakan untuk mengetahui hubungan antara kedua variabel. Analisis dilakukan dengan menggunakan bantuan SPSS Statistics 25 for Windows.

Tabel 1. Hasil Uji Korelasional

\begin{tabular}{llcr}
\hline & & $\begin{array}{r}\text { Work Family } \\
\text { Conflict }\end{array}$ & Pengembangan Karier \\
\hline Work Family & Pearson & 1 & $-.416^{* *}$ \\
Conflict & Correlatio & & .000 \\
& $\mathrm{n}$ Sig. (2-tailed) & & 196 \\
& $\mathrm{~N}$ & 196 & 1 \\
\hline Pengembang an Karier & Pearson & $-.416^{* *}$ & \\
& Correlatio & & 196 \\
& $\mathrm{n}$ & .000 & \\
& Sig. (2-tailed) & 196 & \\
& $\mathrm{~N}$ & & \\
\end{tabular}


Dari Tabel 1 di atas ditentukan bahwa $\mathrm{r}$ hitung memiliki nilai sebesar -0.416. Kemudian ditentukan $\mathrm{r}$ tabel sebesar -0.183 berdasarkan tabel $\mathrm{r}$ (Signifikansi 0.01). Kriteria pengujiannya adalah Ho diterima jika $r$ hitung $>r$ tabel, sedangkan Ho ditolak jika $r$ hitung $<r$ tabel. Karena $r$ hitung $>r$ tabel $(-0.416>$ -0.183) maka dapat disimpulkan bahwa Ho ditolak, artinya work family conflict dan pengembangan karier memiliki pengaruh, yakni pengaruh yang bersifat negatif.

Dengan demikian work family conflict memiliki hubungan negatif terhadap pengembangan karier pada anggota kepolisian di Ditreskrimum Polda Sumatera Utara. Artinya, semakin tinggi atau seringnya work family conflict yang terjadi, maka akan semakin rendah pengembangan karier yang dialami, sebaliknya semakin rendah work family conflict yang terjadi, maka semakin tinggi pengembangan karier yang dialami.

Tabel 2. Hasil Sumbangan Efektif Variabel

\begin{tabular}{ccccc}
\hline Model & R & R Square & $\begin{array}{c}\text { Adjusted } R \\
\text { Square }\end{array}$ & $\begin{array}{c}\text { Std. Error of the } \\
\text { Estimate }\end{array}$ \\
\hline 1 & $.416^{\mathrm{a}}$ & .173 & .169 & 12.80014 \\
\hline
\end{tabular}

Berdasarkakan tabel di atas dapat dilihat pada penelitian ini diperoleh koefisien determinasi Adjust $R$ Square 0.169 . Dengan hasil tersebut dapat disimpulkan bahwa sumbangan $16.9 \%$ work family conflict mempengaruhi pengembangan karier, dengan selebihnya $83,1 \%$ dipengaruhi oleh faktor lain, seperti gaya kepemimpinan, motivasi kerja, dan kedisiplinan.

Hasil di atas menunjukkan bahwa adanya hubungan yang bersifat negatif dari variabel work family conflict terhadap variabel pengembangan karier. Dengan hasil ini artinya bahwa semakin tinggi work family conflict yang dialami maka semakin melemahnya atau terhambatnya pengembangan karier seorang anggota polisi, sebaliknya semakin rendah work family conflict maka pengembangan karier seorang anggota polisi meningkat dan menjadi tidak terhambat. Hasil ini dapat didukung juga oleh penelitian Yusuf [5] yang menyatakan bahwa ada hubungan negatif antara work family conflict terhadap pengembangan karier. Kemudian pada penelitian Wang [10] menyatakan pernikahan dan keluarga telah memengaruhi banyak keputusan kerja dan hasil karier lulusan dengan cara yang kompleks, di mana lebih memberikan efek terhadap perempuan dibanding dengan laki- laki. Dengan sumber keuntungan yang lebih sedikit untuk berinvestasi di tempat kerja, kinerja perempuan mungkin sedikit menderita dan pada gilirannya kemampuan mereka untuk mendapatkan promosi dan imbalan keuangan lebih kecil. Sebaliknya, stabilisasi pribadi dan dukungan yang telah ditunjukkan laki-laki untuk memperoleh keuntungan dari keluarga dapat memungkinkan mereka untuk menyerahkan lebih banyak sumber penghasilan terhadap pekerjaannya.

Selanjutnya hasil ini juga diperkuat dengan penelitian Nurak [12] terhadap pekerja perempuan di Indonesia yang mengatakan adanya perbedaan antara perilaku yang diinginkan oleh bagian kedua (keluarga atau pekerjaan), maka pada seorang wanita tidak mampu mengembangkan karier dengan baik. Demikian pula, pada wanita yang merasa bahwa pola perilaku yang terkait dengan satu peran memiliki kemungkinan memiliki ketidaksesuaian dengan harapan dalam fungsi lain yang akan menghambat perkembangan karier mereka. Dengan kata lain, ketika perilaku yang diperlukan dalam satu peran tidak cocok, maka mereka akan mengurangi agresivitas, ketekunan, dan keinginan untuk mendapatkan keseimbangan di kehidupan pribadi dengan pekerjaan. Lebih jauh lagi, wanita yang memiliki keinginan untuk mendapat pekerjaan yang dapat menjamin karier masa depan cenderung dapat berkembang lebih lanjut dan berkemungkinan besar berhasil.

Work family conflict juga dapat memengaruhi komitmen organisasional seorang karyawann di sebuah perusahaan. Jika work family conflict yang dialami seorang karyawan cenderung rendah hal tersebut dapat berdampak terhadap komitmen organisasional yang cenderung meningkat [9]. Berdasarkan hal tersebut membuat seorang karyawan di sebuah perusahaan lebih memperhatikan pekerjaannya di kantor dan mengurangi perhatian bersama keluarga karena karyawan merasa sangat rugi jika keluar 
dari perusahaan. Karyawan dengan komitmen organisasioanal yang tinggi cenderung dapat mempertahankan loyalitasnya terhadap pekerjaan yang sedang dijalakannya serta loyalitas terhadap perusahaan di mana ia bekerja. Selain itu, work family conflict tidak hanya menjadi faktor dalam pengembangan karier seseorang, namun juga harus mendapat dukungan sosial yakni baik dari keluarga, rekan kerja, maupun atasan [8].

Faktor yang dapat memengaruhi pengembangan karier seseorang tidak hanya work family conflict, namun dapat berasal dari gaya kepemimpinan, motivasi kerja, dan kedisiplinan. Priyono [16] dalam penelitiannya menjelaskan semakin baik gaya kepemimpinan di sebuah instansi maka semakin baik pula pengembangan karier yang akan didapat oleh seorang karyawan, sebaliknya jika gaya kepemimpinan yang ada di sebuah instansi rendah atau buruk maka pengembangan karier yang didapat seorang karyawan akan semakin rendah. Pada penelitiannya juga dijelaskan selain gaya kepemimpinan yang digunakan di dalam instansi, motivasi kerja dan kedisiplinan juga ikut menjadi faktor yang berpengaruh terhadap pengembangan karier seseorang.

Manfaat dalam pengembangan karier tentunya tidak hanya dapat dirasakan oleh pekerja atau karyawan itu sendiri melainkan juga dapat dirasakan oleh perusahaan yang memberikan kesempatan bagi karyawannya untuk mengembangkan karier, Handoko [17] menjelaskan manfaat yang diperoleh organisasi atau departemen personalia yang terlibat dalam perencanaan dan pengembangan karier adalah dapat mengembangkan para karyawan yang dapat dipromosikan; menurunkan perputaran karyawan; mengungkap potensi karyawan; mendorong pertumbuhan; mengurangi penimbunan; memuaskan kebutuhan karyawan; dan membantu pelaksanaan rencana - rencana kegiatan yang telah disetujui.

Tidak hanya sebagai faktor yang dipengaruhi, pengembangan karier juga dapat memengaruhi beberapa hal. Salah satunya adalah prestasi kerja, pengembangan karier yang baik akan mendukung terciptanya prestasi kerja yang baik [4]. Lebih lanjut, Alwi [4] mengatakan implementasi pengembangan karier dapat dilakukan dengan melakukan pelatihan dan pengembangan melaui on the job learning, sistem mentoring dan pembinaan. Kegiatan tersebut bertujuan untuk mempersiapkan keahlian dan kemampuan karyawan agar bisa mempunyai tujuan yang ingin dicapai.

Selanjutnya, dalam penelitian Bahri [18] menjelaskan bahwa pengembangan karier, kompetensi kerja, serta produktivitas kerja bersama-sama memengaruhi secara positif dan signifikan terhadap kinerja pegawai. Pentingnya pengembangan karier erat hubungannya dengan produktivitas pegawai, loyalitas, tingkat perputaran pegawai, dan kreativitas pegawai. Semakin jelas pelaksanaan pengembangan karier dalam suatu perusahaan akan menyebabkan semakin meningkat produktivitas pegawai, loyalitas, kreativitas pegawai, dan menurunnya tingkat perputaran pegawai [18].

Berdasarkan uraian di atas maka dapat disimpulkan bahwa adanya pengaruh work family conflict terhadap pengembangan karier, yakni pengaruh yang bersifat negatif. Semakin tinggi work family conflict cenderung melemahkan pengembangan karier anggota kepolisian. Sebaliknya semakin rendah work family conflict cenderung menguatkan pengembangan karier anggota kepolisian.

\section{Kesimpulan}

Berdasarkan hasil penelitian, dapat disimpulkan bahwa terdapat pengaruh antara work family conflict terhadap pengembangan karier. Hal ini dapat dilihat dari nilai korelasi $r=-0.416$ dengan signifikansi $p$ $=0.000(\mathrm{p}<0.05)$. Dari hasil nilai korelasi menunjukkan terdapat hubungan yang bersifat negatif dan signifikan dari variabel work family conflict terhadap variabel pengembangan karier. Maka dapat ditarik kesimpulan bahwa work family conflict yang terjadi dan bersifat tinggi atau meningkat cenderung memiliki pengaruh terhadap tingkat pengembangan karier yang di mana pengembangan karier akan menurun atau melemah, sebaliknya jika work family conflict tidak terjadi atau menurun cenderung memiliki pengaruh terhadap tingkat pengembangan karier yang di mana pengembangan karier akan meningkat atau menguat. 
Berikut beberapan saran berdasarkan hasil penelitian tersebut. Pihak kepolisian harus selalu memperhatikan pengembangan karier yang dimiliki oleh seorang anggota kepolisian guna mencapai karier yang diinginkan. Pengembangan karier sangat perlu adanya dalam menunjang peningkatan status terhadap anggota kepolisian dalam suatu kondisi jabatan tertentu. Work-family conflict dapat diminimalkan oleh instansi terkait mengenai pengaturan jadwal dan waktu serta tekanan dalam tugas yang harus di perhatikan. Pengembangan karier merupakan kuncinya efektivitas penunjang dalam pekerjaan kepolisian. Agar instansi kepolisian memperhatikan ketidakseimbangan antara tugas dan keluarga yang dibebankan kepada anggotanya guna mengurangi permasalahan dan tekanan yang berdampak kepada pengembangan karir anggota kepolisian tersebut.

\section{Daftar Pustaka}

[1] J. Argenti, Your Organization: What Is It For?: Challenging Traditional Organizational Aims. London: Routledge, 2018.

[2] R. K. Lippert and K. Walby, A Criminology of Policing and Security Frontiers. Bristol: Bristol University Press, 2019.

[3] M. Tang, Career Development and Counseling: Theory and Practice and Multicultural World. Washington DC: SAGE Publications, 2018.

[4] D. Wahyuni, H. N. Utami and I. Ruhana, "Pengaruh Pengembangan Karier Terhadap Prestasi Kerja Karyawan (Studi Pada Karyawan Tetap PT. Astra International, Tbk Daihatsu Malang)," J. Administrasi Bisnis., vol. 8, no. 1, pp. 1-10, 2014.

[5] A. M. Yusuf and Hasnidar, "Work-Family Conflict and Career Development on Performance of Married Women Employees: Case of Bank Employees, Indonesia," J. Business and Social Science., vol. 9, no. 1, pp. 151-162, 2020.

[6] Andriansyah, HR Plan \& Strategy: Strategi Jitu Pengembangan Sumber Daya Manusia. Jakarta: Raih Asa Sukses, 2016.

[7] A. Utaminingsih, Gender dan Wanita Karir. Malang: UB Press, 2017.

[8] V. Rinantri and A. Sahrah, "Persepsi Pengembangan Karir Ditinjau Dari Konflik Peran Ganda Dan Dukungan Sosial Pada Karyawan Wanita Di PT. Gula Putih Mataram Lampung Tengah,” J. Penelitian Humaniora., vol, 19, no. 2, pp. 179-189, 2014.

[9] D. G. A. S. Utama and D. K. Sintaasih, "Pengaruh Work Family Conflict Dan Kepuasan Kerja Terhadap Komitmen Organisasional Dan TurnOver Intention,” J. Menejemen., vol. 4, no. 11, pp. 3073-3737, 2015.

[10] W. Wang and T. Cho, "Work-Family Conflict Influences on Female's Career Development through Career Expectation,” J. Human Resource and Sustainability Studies., no.1, pp. 43-50, 2013.

[11] Estikomah, "Pengaruh Persepsi Pengembangan Karier dan Fear of Success Terhadap Kesejahteraan Psikologis Polisi Wanita Di Mapolda DIY,” J. Studi Keislaman., vol. 4, no. 2, pp. 220-246, 2018.

[12] L. A. D. Nurak, et al., "The Relationship between Work-Family Conflict, Career Success Orientation and Career Development among Working Women in Indonesia," J. Management Science and Business Adminstration., vol. 4, no. 2, pp. 49-56, 2018.

[13] F. E. B. Setyawan, Pengantar Metodologi Penelitian (Statistika Praktis). Sidoarjo: Zifatama Jawara, 2017.

[14] S. Azwar, Metode Penelitian. Yogyakarta: Pustaka Pelajar, 2016.

[15] S. Azwar, Penyusunan Skala Psikologi. Yogyakarta: Pustaka Pelajar, 2018.

[16] Priyono and A. Rahayu, "Pengaruh Gaya Kepemimpinan Kepala Sekolah, Motivasi Kerja, Dan Kepala Kedisiplinan Terhadap Pengembangan Karier Guru SMK Di Kabupaten Boyolali,” J. Quality., vol 4, no. 1, pp. 25-44, 2016.

[17] A. D. Nugroho and Kunartinah, "Analisis Pengaruh Kompensasi Dan Pengembangan Karier Terhadap Kepuasan Kerja Dengan Mediasi Motivasi Kerja,” J. Bisnis dan Ekonomi., vol. 19, no. 2, pp. 153-169, 2012.

[18] S. Bahri, "Pengaruh Pengambangan Karier Dan Kompetensi Terhadap Produktivitas Kerja Serta Implikasinya Pada Kinerja Pegawai Dinas PU Bina Marga Wilayah Kerja Sumatera Selatan,” J. Ecoment Global., vol. 1, no. 1, pp. 51-61, 2016. 